\title{
A função da história no atendimento de pacientes nos dias de hoje
}

\author{
The role of history in the treatment of patients in the current days
}

\author{
Carmem Keidann* \\ * Editora, Rev Psiquiatr RS.
}

Neste número da Revista, a ênfase dos editoriais recai sobre a história. Há alguns olhares possíveis sobre o assunto: a história da psiquiatria, dos atendimentos psiquiátrico e psicoterápico, a história e o desenvolvimento das teorias que sustentam o trabalho científico do psiquiatra. Há também histórias relacionadas com a evolução do atendimento a pacientes e, nesse sentido, mais um possível vértice de reflexão se revela, que diz respeito à história de vida dos pacientes e à história do atendimento que se desenvolve ao longo do processo.

Podemos, pois, fazer uma conexão entre o trabalho do psiquiatra com seu paciente e a inserção da história pessoal do paciente naquela que passa a ser construída pela dupla paciente-psiquiatra.

No atendimento ao paciente, ao avaliar os sintomas e/ou problemas trazidos para a consulta desde a avaliação, o profissional está lidando com história. A história da pessoa é fator diagnóstico primordial. Através desta, pode-se avaliar o padrão de funcionamento do paciente e de suas relações familiares, e esses dados são fundamentais tanto para o atendimento clínico-farmacológico quanto para o psicoterápico. Os dados da história do paciente, como viveu e o que conseguiu realizar, apesar da doença, possibilitam um diagnóstico adequado e uma indicação mais específica de tratamento.

Especialmente na abordagem psicoterápica, percebe-se o interesse pela história do indivíduo, pela forma como ele foi constituindo sua subjetividade e como vem lidando com seu sofrimento. Tais dados vão sendo integrados na mente do psiquiatra, e a compreensão do modo como o paciente compartilha e seleciona os fatos para contar acabam por dar forma e conduzir a história do atendimento psicoterápico em si. Constata-se, ao longo dos atendimentos, que a versão dos pacientes sobre dados de sua história sofre mudanças, relacionadas ao momento de vida e também ao momento do tratamento. Portanto, a história vai sendo construída, e os personagens adquirem novas feições à medida que a compreensão do paciente se amplia.

Recentemente, o sociólogo americano Immanuel Wallerstein, da Universidade de Yale, esteve em Porto Alegre participando de um ciclo de atividades chamado "Fronteiras do pensamento". Numa entrevista concedida ao jornal local, ele comentou algo que se aplica às idéias que ora trazemos. Disse Wallerstein: “(...) Os fatos estão lá, eles também são criações. Nós não abordamos a história do universo quando escrevemos história; selecionamos o que faz sentido. E chamamos isso de fatos!"!

Tal concepção sobre história reitera sua importância no trabalho clínico com pacientes. $\mathrm{O}$ psiquiatra busca fatos que lhe façam sentido, para então poder formar uma idéia sobre o paciente e sobre a conduta terapêutica a ser seguida. E também para que possa ajudar o paciente no encontro de significados para as emoções e fatos trazidos ou lembrados por ele. $\mathrm{O}$ profissional deve acompanhar seu paciente nesse caminho tanto quanto for necessário. Mas deve reconhecer que sua função é conduzir o tratamento, e não a vida do paciente, e esta é uma recomendação ética importante a enfatizar ${ }^{2}$.

É bom lembrar que somos agentes ativos e passivos da história. Ao exercer a profissão de psiquiatra e ao organizar uma revista, enfocando, nos editoriais, a história da psiquiatria, estamos funcionando como agentes ativos, já que estamos tratando de comunicar algo que já se inscreveu ao longo do tempo. O peso da história da profissão recai sobre cada indivíduo, e como nossa função é, em grande parte, determinada por sua história, também somos seus agentes passivos. Há responsabilidades que o conhecimento implica. A identidade da profissão está inevitavelmente associada à sua história. É essencial que se possa respeitar suas origens e desenvolvimento. 
Assim, neste número, buscamos trazer aos leitores lembranças do início da psiquiatria em nosso país. Contrastando com o último número, em que conjeturamos sobre o futuro, pensamos em revisitar o passado para possibilitar uma retrospectiva que nos permitisse acompanhar um caminho já percorrido e, aprendendo com as experiências acumuladas, seguir evoluindo.

Convidamos para a apresentação da capa o colega Walmor Piccinini, que nos leva ao passado com a apreciação histórica e comentários pertinentes e esclarecedores sobre as imagens contidas na foto.

Em seguida, temos três editoriais a convite assinados por colegas de reconhecida experiência na psiquiatria brasileira. Othon Bastos Filho e Luiz Salvador de Miranda-Sá Júnior enriquecem o tema com aspectos da história da psiquiatria no Brasil, relacionando aspectos contextuais históricos com a prática da psiquiatria nos seus primórdios. Dr. Sérgio Annes, um dos colegas aqui do nosso Estado, faz um relato pessoal de sua experiência, compartilhando conosco sua trajetória como psiquiatra e psicanalista.

Desejamos a todos uma boa e enriquecedora leitura.

\section{Referências}

1. Wallerstein I. [entrevista]. Caderno de Cultura. Zero Hora, 25/08/ 07.

2. Cruz JG, Golbert SI. Ética em psicoterapia de orientação analítica. Rev Bras Psicoter. 2005;7(1):61-72. 